\title{
Multisystem inflammatory syndrome in children-associated with severe acute respiratory syndrome coronavirus 2: A case report and brief review of literature
}

\author{
Prashant Prakash Rajebhosale ${ }^{1}$, Mohammad Mousa Aldisi², Wissam Jamal Altamr ${ }^{3}$ \\ From ${ }^{1}$ Specialist Pediatrician and Specialist PICU, ${ }^{2}$ Consultant and Head, ${ }^{3}$ Specialist Pediatric Surgeon, Department of Pediatrics, Al Zahra Hospital, \\ Sharjah, United Arab Emirates
}

\begin{abstract}
Amid coronavirus disease (COVID-19) pandemic, recently a number of children who developed a significant systemic inflammatory response have been identified from various parts of the world. This syndrome has been described to have clinical features closely related to Kawasaki disease, toxic shock syndromes, bacterial sepsis, and macrophage activation syndromes. Clinical and laboratory manifestations of this multisystem inflammatory syndrome have been attributed to the antibodies produced against severe acute respiratory syndrome coronavirus 2 (SARS-CoV-2). Here, we report a case of a previously well 4-year-old female child who presented to us with multisystem inflammatory syndrome in children (MIS-C) following exposure to SARS-CoV-2 and was successfully managed with intravenous immunoglobulin (IVIGg) and IV steroids.
\end{abstract}

Key words: MIS-C, COVID-19, SARS-CoV-2, PIM-TS

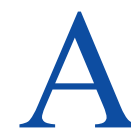

s of August 31, 2020, more than 25.1 million confirmed cases of coronavirus disease (COVID-19) including more than 844,000 deaths have been reported worldwide [1]. Limited data describe clinical manifestations of COVID-19 generally milder in children compared with adults but also show that some children do require hospitalization and intensive care support. Recently, a limited number of children with exposure to COVID-19 virus who developed significant systemic inflammatory response syndrome with clinical features overlapping with Kawasaki disease (KD) and toxic shock syndrome have been identified from Europe, North America, and various parts of the world [2]. This syndrome has been described in children after 2-4 weeks of exposure to COVID-19 virus suggesting aberrant cellular and humoral immune response to the virus [3]. This syndrome has been labeled by different terminologies such as multisystem inflammatory syndrome in children (MIS-C) associated with severe acute respiratory syndrome coronavirus 2 (SARS-CoV-2) [4], pediatric multisystem inflammatory syndrome temporally associated with SARS-CoV-2 (PIM-TS) [5], and hyperinflammatory shock during COVID-19 pandemic [6].

Clinical and laboratory manifestations of MIS-C have been attributed to the antibodies produced against SARS-CoV-2. It has

\section{Access this article online}

Received - 01 August 2020

Initial Review - 25 August 2020

Accepted - 14 September 2020

DOI: 10.32677/IJCH.2020.v07.i09.009 been postulated that these antibodies enhance the severity of infection by triggering inflammation or mediating organ damage [3]. Clinical similarity between KD and MIS-C implies a related underlying genetic architecture, supporting the hypothesis that the new disorder arises from aberrant T- or B-cell responses to SARS-CoV-2 [7].

MIS-C shares overlapping clinical features with $\mathrm{KD}$ such as conjunctival injection, oropharyngeal findings (red and/ or cracked lips and strawberry tongue), rash, swollen and/or erythematous hands and feet, and cervical lymphadenopathy. However, some notable differences from $\mathrm{KD}$ include broader age range of presentation, more prominent gastrointestinal and neurological symptoms, more frequent presentation with shock, and more likely to display cardiac dysfunction (arrhythmias and ventricular dysfunction) [8]. Here, we report a case of a previously well 4-year-old female child who presented to us with MIS-C following exposure to SARS-CoV-2 and was successfully managed with intravenous immunoglobulin (IVIG) and intravenous (IV) steroids.

\section{CASE REPORT}

A 4-year-old female child who was previously well was brought with complaints of high- grade fever $\left(>39^{\circ} \mathrm{C}\right)$, vomiting, and loose motions for 4 days. She developed a non-itchy, generalized rash all over the body 2 days before admission. It initially started

Correspondence to: Dr. Prashant Prakash Rajebhosale, Specialist Pediatrician and PICU, Department of Pediatrics, Al Zahra Hospital, Sharjah, Al Zahra Street, Near Clock Tower, Sharjah - 3499, United Arab Emirates. E-mail:dr. pprajebhosale@gmail.com

(C) 2020 Creative Commons Attribution-NonCommercial 4.0 International License (CC BY-NC-ND 4.0). 
over the trunk and then spread to involve limbs and face. At the time of admission, she was alert, with heart rate of $124 / \mathrm{min}$, respiratory rate of $40 / \mathrm{min}$, her blood pressure was $74 / 30 \mathrm{~mm}$ $\mathrm{Hg}$ and she had features of warm shock. Her body mass index (BMI) was $27 \mathrm{~kg} / \mathrm{m}^{2}$. On physical examination, it was noticed that she had generalized maculopapular, erythematous rash all over the body predominantly over the trunk (Fig. 1). She also had hepatomegaly, cracked lips, and edema of the limbs. She was initially managed with isotonic fluid boluses and IV antibiotics. However, in view of repeated episodes of hypotension, decreased urine output along with a drop in Glasgow Coma Scale (GCS) to $10 / 15$ she was shifted to pediatric intensive care unit (PICU) for further care.

Initial investigations done revealed neutrophilic leukocytosis (total leukocyte count [TLC] 15400/ $\mu \mathrm{L}, \mathrm{N} 88.8 \%$, L 7.5\%) with thrombocytopenia $61,000 / \mu \mathrm{L}$. Her acute phase reactants were elevated (C-reactive protein [CRP] $139 \mathrm{mg} / \mathrm{L}$, serum ferritin $667 \mathrm{ng} / \mathrm{mL}$, procalcitonin test [PCT] $88 \mathrm{ng} / \mathrm{mL}$, and D-dimer $3446 \mathrm{ng} / \mathrm{mL}$ ) and liver function was deranged with serum bilirubin $41 \mathrm{umol} / \mathrm{L}$ (direct: $33 \mathrm{umol} / \mathrm{L}$, and indirect: $8 \mathrm{umol} / \mathrm{L}$ ), and elevated liver enzymes (SGOT $130 \mathrm{IU} / \mathrm{L}$, SGPT $76 \mathrm{IU} / \mathrm{L}$ ) with hypoalbuminemia $(2.8 \mathrm{~g} / \mathrm{dL})$. Her coagulation profile revealed deranged international normalized ratio (INR) 1.7 and other coagulation parameters including activated partial thromboplastin time (APTT) $(29.8 \mathrm{~s})$, serum fibrinogen $(4.54 \mathrm{~g} / \mathrm{L})$, and thrombin time (14.1 s) were normal. Renal function test was normal except hyponatremia (serum sodium $131 \mathrm{meq} / \mathrm{L}$ ) and INR was 1.7 . Her serum triglyceride level was increased $(457 \mathrm{mg} / \mathrm{dL})$, while serum troponin-I level was normal. Blood and urine culture were sterile. Transthoracic echocardiography was normal. Real-time reversetranscriptase polymerase chain reaction (RT-PCR) for COVID-19 was negative twice.

Nasopharyngeal swabs for streptococcus, influenza A, and influenza B were negative. Ultrasound abdomen was suggestive of non-calculous cholecystitis. Chest X-ray was suggestive of ground glass appearance in both lung fields with patchy opacities in the right infra hilar region. There was a history of exposure to COVID-19 patient in the family nearly 2 weeks before (maternal uncle).

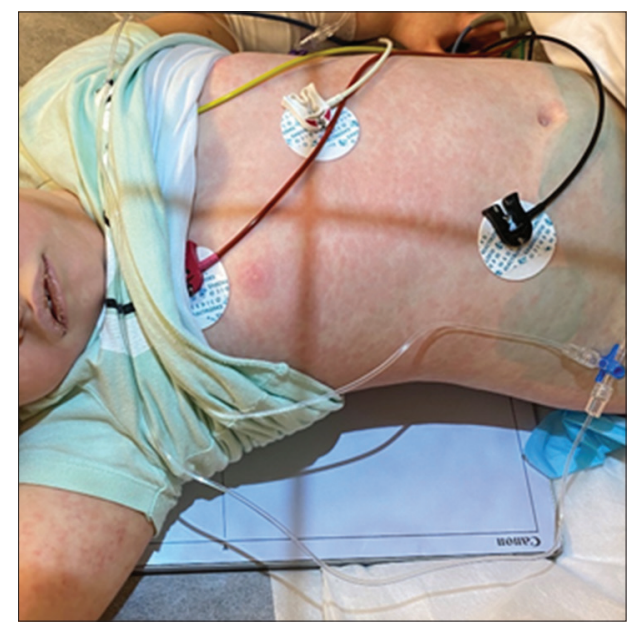

Figure 1: Generalized, maculopapular, erythematous rash all over the body predominantly over the trunk with cracked lips
She was started on broad spectrum antibiotics (Inj. meropenem and Inj. vancomycin), inopressors (Inj adrenaline and noradrenaline infusion). Later, Inj. hydrocortisone was added in view of fluid and catecholamine refractory shock. With these measures, her blood pressure improved. IVIG $2 \mathrm{~g} / \mathrm{kg}$ was given over $24 \mathrm{~h}$. Her fever spikes subsided within $16 \mathrm{~h}$ of administration of IVIG and inopressors were tapered and stopped over next $36 \mathrm{~h}$. Her inflammatory markers started showing improvement in the next $48 \mathrm{~h}$ (Table 1 ).

Her TLC remained elevated till discharge $(20400 / \mu \mathrm{L}, \mathrm{N} 68.5$, L 25.4). However, she was clinically improving and on follow-up 1 -week post-discharge TLC was documented as normal $(11500 / \mu \mathrm{L}$ $\mathrm{N}$ 58.4, L 36.7). Her platelet count became normal 96 h postIVIg infusion $(224,000 / \mu \mathrm{L})$. After $48 \mathrm{~h}$ of IVIg administration, her other inflammatory markers showed declining trend and at $96 \mathrm{~h}$ post-IVIg it was significantly low (CRP $17 \mathrm{mg} / \mathrm{dL}$, D-Dimer $1943 \mathrm{ng} / \mathrm{dL}$, and serum ferritin $683 \mathrm{ng} / \mathrm{dL}$ ) and was documented as normal on follow-up 1 week later (CRP $10 \mathrm{mg} / \mathrm{dL}$, serum ferritin $28 \mathrm{ng} / \mathrm{dL}$, and D-dimer $150 \mathrm{ng} / \mathrm{dL}$ ). Her serum bilirubin, liver enzymes and INR rapidly improved within $48 \mathrm{~h}$ post-ICU admission (Total serum bilirubin $7.6 \mathrm{umol} / \mathrm{L}$, direct $3.7 \mathrm{umol} / \mathrm{L}$, SGOT $58 \mathrm{IU} / \mathrm{L}$, SGPT $44 \mathrm{IU} / \mathrm{L}$, and INR 1.3). However, it took $96 \mathrm{~h}$ to normalize total serum protein $(7.6 \mathrm{gm} / \mathrm{dL})$ and serum albumin $(3.7 \mathrm{gm} / \mathrm{dL})$ levels.

As blood and urine cultures were sterile, antibiotics were de-escalated. Her total ICU stay was for 5 days and on $7^{\text {th }}$ day of hospitalization she was discharged.

\section{DISCUSSION}

The COVID-19 pandemic has caused catastrophic disease worldwide, although children have been relatively spared [4]. Respiratory system involvement causing acute respiratory distress syndrome is the most common complication of SARSCoV-2 in adults; however, children often have milder respiratory symptoms [9]. It seems other systems are also susceptible to SARS$\mathrm{CoV}-2$ infection. Increasing evidence suggests that tissue damage in COVID-19 is mostly mediated by the cytokine storm [10].

MIS-C has been defined by certain clinical and laboratory criteria. The case definition of MIS-C included six criteria: Serious illness leading to hospitalization, an age of $<21$ years, fever (body temperature, $>38.0^{\circ} \mathrm{C}$ ) or report of subjective fever lasting at least $24 \mathrm{~h}$, laboratory evidence of inflammation, multisystem organ involvement (i.e., involving at least two systems), and laboratory confirmed SARS-CoV-2 infection (positive SARS CoV-2 RT-PCR or antibody test during hospitalization) or an epidemiologic link to a person with COVID-19 [4].

The index case fulfilled all the above-mentioned criteria. In a recently published study involving 186 patients from the USA, [4] the most commonly involved organ systems were the gastrointestinal (171 [92\%]), cardiovascular (149 [80\%]), hematologic (142 [76\%]), mucocutaneous (137 [74\%]), and respiratory (131 [70\%]) systems. Our index patient had involvement of gastrointestinal (diarrhea and vomiting), cardiovascular (warm shock), hematological (thrombocytopenia), 
Table 1: Investigations of the patient

\begin{tabular}{|c|c|c|c|c|c|c|}
\hline Investigation & At admission & $24 \mathrm{~h}$ post IVIG & 48 h post IVIG & $72 \mathrm{~h}$ post IVIG & $96 \mathrm{~h}$ post IVIG & 1 week post discharge \\
\hline Total WBC $(1000 / \mu \mathrm{L})$ & 15.4 & 29.3 & 25.7 & 21.2 & 20.4 & 11.5 \\
\hline Neutrophil \% & 88.8 & 82.2 & 68.5 & 68.1 & 68.5 & 58.4 \\
\hline Lymphocytes \% & 7.5 & 12.1 & 27.8 & 26.4 & 25.4 & 36.7 \\
\hline Platelet count $(1000 / \mu \mathrm{L})$ & 61000 & 55000 & 56000 & 88000 & 254 & 557 \\
\hline $\mathrm{CRP}(\mathrm{mg} / \mathrm{L})$ & 139 & 138 & 71 & 25 & 17 & 10 \\
\hline D-Dimer (ng/dL) & 3446 & 3889 & 3917 & 2871 & 1943 & 150 \\
\hline Ferritin (ng/dL) & 627 & 1016 & 1047 & & 683 & 28 \\
\hline
\end{tabular}

Table 2: Recommended Investigations

\begin{tabular}{|c|c|c|}
\hline Tier & Indication & Investigations \\
\hline Tier I & $\begin{array}{l}\text { 1. Fever }>38^{\circ} \mathrm{C} \\
\text { 2. Epidemiological link to } \\
\text { SARS-CoV-2 } \\
\text { 3. At least } 2 \text { suggestive clinical } \\
\text { features } \\
\text { - Rash } \\
\text { - Gastrointestinal symptoms } \\
\text { - Edema of hands/feet } \\
\text { - Oral mucosal changes } \\
\text { - Conjunctivitis } \\
\text { - Lymphadenopathy } \\
\text { - Neurological symptoms }\end{array}$ & $\begin{array}{l}\text { CBC, CRP, ESR, Serum } \\
\text { electrolytes, glucose, } \\
\text { calcium, Liver function } \\
\text { test, Renal function test, } \\
\text { SARS-CoV2-PCR and/ } \\
\text { or serologies }\end{array}$ \\
\hline Tier 2 & $\begin{array}{l}\text { Tier } 1 \text { investigations showing } \\
\text { All of the following } \\
\text { 1. } \mathrm{CRP} \geq 5 \mathrm{mg} / \mathrm{dL} \text { (more than } \\
\text { or equal to) } \\
\text { 2. Absolute lymphocyte count } \\
<1000 / \mu \mathrm{L} \\
\text { 3. Platelet count }<150,000 / \mu \mathrm{L} \\
\text { 4. Na }<135 \mathrm{mmol} / \mathrm{L} \\
\text { 5. Neutrophilia } \\
\text { 6. Hypoalbuminemia }\end{array}$ & $\begin{array}{l}\text { BNP, Troponin T, } \\
\text { Procalcitonin, ferritin, } \\
\text { PT, PTT, D-dimer, } \\
\text { Fibrinogen, LDH, } \\
\text { Cytokine panel, } \\
\text { triglycerides, ECG, } \\
\text { ECHO, SARS-CoV-2 } \\
\text { serology if not done } \\
\text { already. }\end{array}$ \\
\hline
\end{tabular}

mucocutaneous (cracking of lips), and neurological (low GCS) involvement which was quite similar to the previously reported case.

In the same study, $92 \%$ patients had four or more laboratory biomarkers indicating inflammation [4]. Our patient's inflammatory markers were also high (Table 1). Although her COVID-19 RT-PCR was negative twice, there was a history of exposure to COVID-19 patient (maternal uncle) approximately 2 weeks before symptom onset. We could not perform COVID-19 antibodies due to unavailability of the test in our region.

In a case series reported by Riphagen et al., out of eight children, seven tested negative for SARS-CoV-2 on bronchoalveolar lavage or nasopharyngeal aspirate and one child tested positive for SARS-CoV-19 on postmortem examination [6]. Work up for other etiology in our patient, including blood and urine culture along with respiratory viral panel PCR were non-contributory which further supported our diagnosis.

In the same case series by Riphagen et al., all patients were treated with IVIG along with other immunomodulatory drugs which included methylprednisolone (four patients), aspirin (three patients), hydrocortisone (one patient), and infliximab (one patient) [6]. Our patient responded promptly to IVIG infusion (2 $\mathrm{gm} / \mathrm{kg}$ ) and Inj. hydrocortisone. Initially, we started Inj.
Table 3: Immunomodulatory treatment recommended

\begin{tabular}{|c|c|c|}
\hline Therapy & Agent & Comments \\
\hline $\begin{array}{l}\text { First tier } \\
\text { therapy }\end{array}$ & $\begin{array}{l}\text { IVIG and/or } \\
\text { glucocorticoids }\end{array}$ & $\begin{array}{l}\text { - IVIG } 1 \text { to } 2 \text { gm/kg } \\
\text { - Glucocorticoids: Low-moderate dose } \\
\text { glucocorticoids } 1-2 \mathrm{mg} / \mathrm{kg} / \text { day. } \\
\text { - High dose/pulse steroids considered } \\
\text { in presence of life-threatening } \\
\text { complications, such as shock, and } \\
\text { specifically, if a patient requires high } \\
\text { dose or multiple inotropes and/or } \\
\text { vasopressors. } \\
\text { - Tapering of steroid done over } 2-3 \\
\text { weeks to avoid rebound inflammation. }\end{array}$ \\
\hline $\begin{array}{l}\text { Second tier } \\
\text { therapy }\end{array}$ & Anakinra & $\begin{array}{l}\text { Considered for treatment of MIS-C } \\
\text { refractory to IVIG and glucocorticoids } \\
\text { or in patients with contraindications to } \\
\text { these treatments. } \\
\text { Dose: } 4 \mathrm{mg} / \mathrm{kg} / \text { day (IV or } \\
\text { subcutaneous). }\end{array}$ \\
\hline
\end{tabular}

hydrocortisone to achieve hemodynamic stability but in view of dramatic response to IVIG and steroids, we continued Inj. hydrocortisone for 1 week. We also started low dose aspirin once her platelet count started improving.

In all other publications, IVIG was used as a first line agent and other immunomodulatory drugs were used if there was no or poor response to IVIG [4-6,10,11]. In one of the studies conducted in the United Kingdom, it was observed that nearly $22 \%$ patients with MIS-C recovered with supportive care alone; therefore, watchful expectancy can be considered as an option in stable children with mild symptoms [12]. Based on recent recommendations by American College of Rheumatology, we have formulated flowchart and tables for approach and management of a child with suspected MIS-C (Tables 2-4 and Flowchart 1) [8].

A team of researchers from Children's Hospital of Geneva revealed the case of three adolescents who developed septic shock secondary to the corona virus infection. All three patients were obese with a BMI higher than the $97^{\text {th }}$ percentile for age [13]. Our patient's BMI was also $>97^{\text {th }}$ percentile $\left(27 \mathrm{~kg} / \mathrm{m}^{2}\right)$. Hence, obesity may be an important risk factor for severe COVID-19 related illness apart from chronic kidney disease undergoing dialysis, chronic liver diseases, and endocrine disorders (e.g., diabetes mellitus) [13]. Overall, ICU stay in all these studies has been approximately $4-5$ days which is very similar to our case $[4,6,9]$. 
Table 4: Antiplatelet and anticoagulation therapy in MIS-C

\begin{tabular}{|c|c|c|}
\hline Drug & Indication & Comment \\
\hline $\begin{array}{l}\text { Low dose aspirin }(3-5 \\
\mathrm{mg} / \mathrm{kg} / \text { day; } \max 81 \\
\mathrm{mg} / \text { day })\end{array}$ & $\begin{array}{l}\text { (a) MIS-C and KD-like features and } / \text { or } \\
\text { thrombocytosis (platelet count } \geq 450,000 / \mu \mathrm{L} \text { ) } \\
\text { (b) MIS-C patients with coronary artery abnormalities } \\
\text { (CAAs) and a maximal z-score of } 2.5-10.0\end{array}$ & $\begin{array}{l}\text { (a) Continued until normalization of platelet count and confirmed } \\
\text { normal coronary arteries at } \geq 4 \text { weeks after diagnosis. } \\
\text { (b) Contraindicated in patients with platelet count } \leq 80,000 / \mu \mathrm{L} \text {. }\end{array}$ \\
\hline $\begin{array}{l}\text { Low dose aspirin } \\
\text { and therapeutic } \\
\text { anticoagulation } \\
\text { (Enoxaparin or } \\
\text { warfarin) }\end{array}$ & $\begin{array}{l}\text { MIS-C patients with CAAs z-score } \geq 10.0 \\
\text { MIS-C with documented thrombosis or an ejection } \\
\text { fraction }(E F)<35 \%\end{array}$ & $\begin{array}{l}\text { Treatment duration } \\
\text { (a) CAA with z-score >10.0: Indefinite treatment } \\
\text { (b) Documented thrombosis: Treatment for } \geq 3 \text { months pending } \\
\text { thrombus resolution } \\
\text { (c) Ongoing moderate to severe LV dysfunction: Prolonged } \\
\text { duration (Duration depending on improvement in LV dysfunction) }\end{array}$ \\
\hline
\end{tabular}

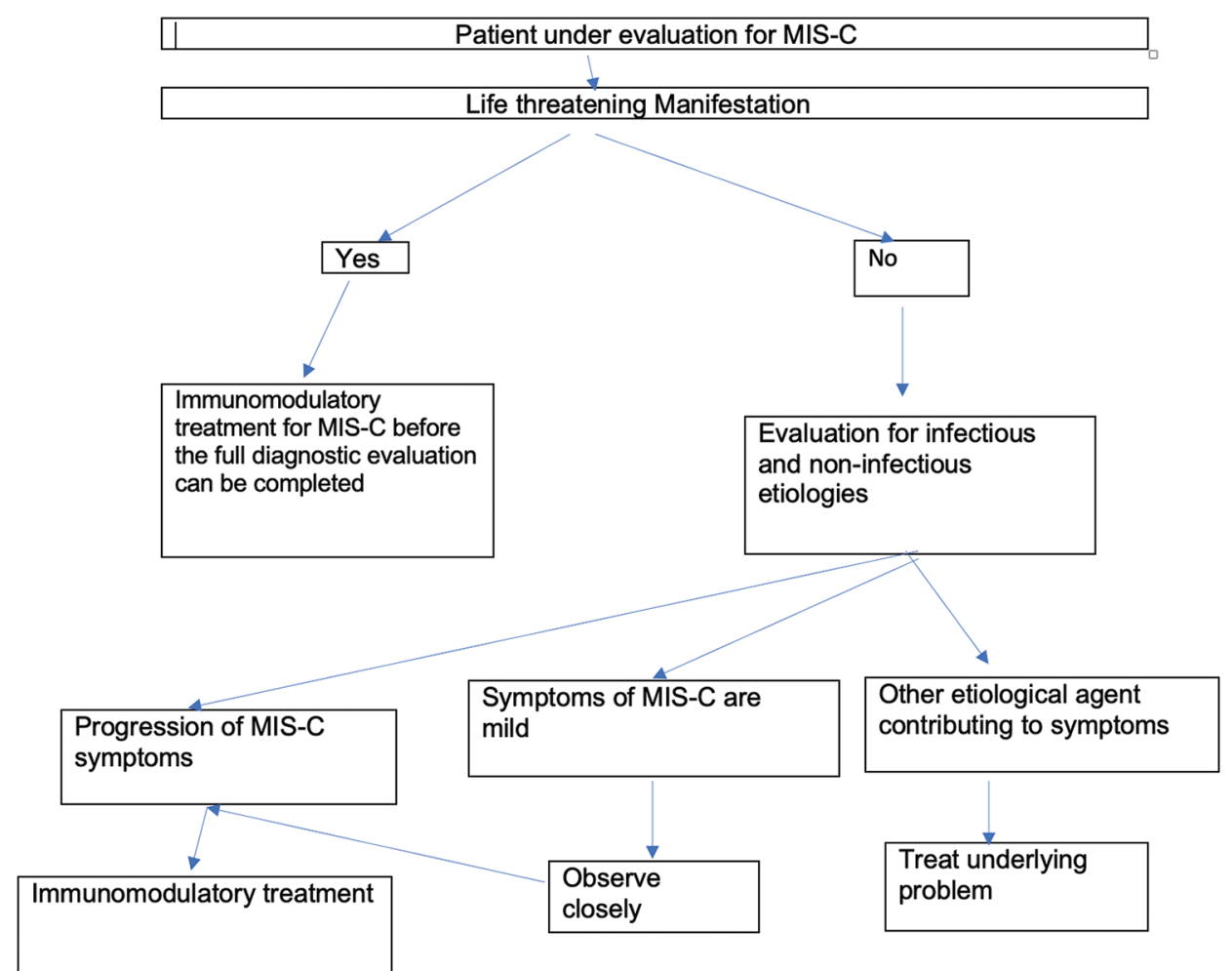

Flowchart 1: Approach and management of child with suspected MIS-C

Early recognition and aggressive intensive care support have led to low mortality in all these studies $[4,6,10]$. In one of the largest studies involving 186 children with MIS-C only four children died out of which two had underlying comorbid conditions [4].

Finally, in the USA and Europe, this entity was observed more frequently during the descent of epidemic rather than during the community transmission phase $[4,14]$. Therefore, we hypothesize that in the forthcoming days countries like India where COVID-19 cases are still rising might observe a surge in cases of MIS-C.e

\section{CONCLUSION}

MIS-C is an increasingly recognized entity in various parts of the world and pediatricians should be vigilant about such presentation.
Early treatment with IVIG and other immunomodulatory drugs can drastically improve the outcomes.

\section{REFERENCES}

1. Coronavirus Outbreak. Available from: http://www.worldometers.info/ coronavirus. [Last accessed on 2020 Aug 31].

2. Available from: https://www.who.int/news-room/commentaries/detail/ multisystem-inflammatory-syndrome-in-children-and-adolescents-withcovid-19. [Last accessed on 2020 May 17].

3. Liu L, Wei Q, Lin Q, Fang J, Wang H, Kwok H, et al. Anti-spike IgG causes severe acute lung injury by skewing macrophage responses during acute SARS-CoV infection. JCI Insight 2019;4:e123158.

4. Feldstein LR, Rose EB, Horwitz SM, Collins JP, Newhams MM, Son MB, et al. Multisystem inflammatory syndrome in U.S. children and adolescents. N Engl J Med 2020;383:334-46.

5. RCPCH. Guidance-Paediatric Multisystem Inflammatory Syndrome Temporally Associated with COVID-19. Available from: https://www.rcpch. ac.uk/sites/default/files/2020-05/COVID-19-Paediatric-multisystem-\%20 inflammatory\%20syndrome-20200501.pdf. 
6. Riphagen S, Gomez X, Gonzalez-Martinez C, Wilkinson N, Theocharis P. Hyperinflammatory shock in children during COVID-19 pandemic. Lancet 2020;395:1607-8.

7. Levin M. Childhood multisystem inflammatory syndrome-a new challenge in the pandemic. N Engl J Med 2020;383:393-5.

8. Henderson LA, Canna SW, Friedman KG, Gorelik M, Lapidus SK, Bassiri H, et al. American College of Rheumatology clinical guidance for pediatric patients with multisystem inflammatory syndrome in children (MIS-C) associated with SARS-CoV-2 and hyperinflammation in COVID-19. Version 1. Arthritis Rheumatol 2020;2020:41454

9. Ciuca IM. COVID-19 in children: An ample review. Risk Manag Healthc Policy 2020;13:661-9.

10. Mehta P, McAuley DF, Brown M, Sanchez E, Tattersall RS, Manson JJ, et al. COVID-19: Consider cytokine storm syndromes and immunosuppression. Lancet 2020;395:1033-4.

11. Balasubramanian S, Nagendran TM, Ramachandran B, Ramanan AV. Hyperinflammatory syndrome in a child with COVID-19 treated successfully with intravenous immunoglobulin and tocilizumab. Indian Pediatr 2020;57:681-3.

12. Whittaker E, Bamford A, Kenny J, Kaforou M, Jones CE, Shah P, et al. Clinical characteristics of 58 children with a pediatric inflammatory multisystem syndrome temporally associated with SARS-CoV-2. JAMA 2020;324:259-69.

13. Dallan C, Romano F, Siebert J, Politi S, Lacroix L, Sahyoun C. Septic shock presentation in adolescents with COVID-19. Lancet Child Adolesc Health 2020;4:e21-3.

14. Belot A, Antona D, Renolleau S, Javouhey E, Hentgen V, Angoulvant F, et al. SARS-CoV-2-related paediatric inflammatory multisystem syndrome, an epidemiological study, France, 1 March to 17 May 2020. Euro Surveill 2020;25:2001010.

Funding: None; Conflicts of Interest: None Stated.

How to cite this article: Rajebhosale PP, Aldisi MM, Altamr WJ. Multisystem inflammatory syndrome in children-associated with severe acute respiratory syndrome coronavirus 2: A case report and brief review of literature. Indian J Child Health. 2020; 7(9):393-397. 